\title{
Influence of Irrigation and Wetting Agent on Fungicide Residues in Creeping Bentgrass
}

\author{
Richard Latin ${ }^{\dagger}$ and Ling Ou, Purdue University, West Lafayette, IN
}

\begin{abstract}
Fungicides (azoxystrobin, propiconazole, pyraclostrobin, and thiophanatemethyl) were applied to field plots of creeping bentgrass established on a sand-based root zone substrate and maintained at a cutting height of $0.34 \mathrm{~cm}$. The wetting agent, a modified alkylated polyol, was applied $24 \mathrm{~h}$ prior to fungicide application. Irrigation $(0.51 \mathrm{~cm})$ was applied to plots immediately after the fungicide spray. Turf was sampled nine times over 42 days to examine fungicide residues in three components of the turf profile: verdure/thatch, roots, and soil. Residues were extracted from samples and then quantified using a liquid

chromatography-mass spectrometry/mass spectrometry (LC-MS/MS) procedure. The experiment was run twice. Wetting agent had little or no effect on fungicide distribution in any of the turf components. Postapplication irrigation had little effect on residues observed in the verdure/ thatch component. Significant irrigation treatment effects were observed in root and soil components, but results varied among fungicides and sampling dates. Where significant effects were observed for the irrigation plus wetting agent treatment, results generally mirrored outcomes for irrigation treatment.
\end{abstract}

Fungicides are routinely applied to creeping bentgrass on golf courses to protect against diseases that may disturb aesthetic and structural qualities of playing surfaces. Diseases affecting creeping bentgrass are caused by a variety of pathogens (mostly fungal) that attack aboveand belowground plant parts. Managing root diseases is especially challenging because pathogen biology and ecology are not well understood, and the extent of turf damage is often correlated with levels of environmental stress. The primary approach is to practice sound agronomy, promoting healthy dense root systems that are better able to tolerate infection and environmental extremes. Cultural practices aimed at stress relief often are inadequate in preventing serious turf damage, thereby justifying decisions to pursue chemical control options. Control with fungicides is often inconsistent because, unlike leaf and shoot pathogens, root pathogens are buried beneath turf surfaces and shielded from direct foliar sprays. Furthermore, compounds effective against root pathogens do not move in a basipetal fashion to reach root tissues from within the plant. Of all fungicides registered for use on amenity grasses, only those in the phosphonate class are ambimobile, i.e., they move upward to new growth and downward to roots through the symplast (Hsu and Kleier 1996). Unfortunately, phosphonates have no potency against the most serious root infecting fungi such as Magnaporthe poae, Gaeumannomyces graminis f. sp. avenae, and Ophiosphaerella spp. Fungicides that effectively limit growth of fungal root pathogens move in the apoplast and are characterized by acropetal or translaminar transport. They diffuse into plants, but either move across the cell matrix in a translaminar fashion (local penetrants) or are xylem mobile, moving acropetally, upward and outward with the water stream (Latin 2011).

From a practical perspective, chemical control of root diseases on turf is predicated on the delivery of fungicide below turf surfaces by water-by increasing water volume of the spray and/or by applying supplemental irrigation. Turf managers often apply wetting agents prior to fungicide sprays that, according to anecdotal information, may facilitate movement of fungicide below the turf surface. Most product labels for fungicides registered for root disease control contain language suggesting increased volumes of water to address root diseases. Wong and Corza (2005) reported on summer patch (caused by $M$. poae) control with a variety of modern penetrant fungicides applied as a foliar spray with the equivalent of 815 and 1,628 liter ha ${ }^{-1}$. They found no difference in control between QoI fungicides

${ }^{\dagger}$ Corresponding author: R. Latin; E-mail: rlatin@purdue.edu

Accepted for publication 7 May 2018.

@ 2018 The American Phytopathological Society (azoxystrobin and pyraclostrobin) applied at different intervals and rates for both application volumes. Similarly, most evidence on wetting agent influence is in the form of single-season reports that document observed treatment effects in a given season (Dernoeden et al. 2002; Earlywine and Miller 2015; Fidanza and McDonald 2007; Fidanza et al. 2002; Kaminski 2008; Wong and Rios 2008). Although such reports provide food for thought, interpretations are often clouded by confounding factors such as postoutbreak (curative) application, or inconsistent or ephemeral significance in treatment effects. Reports document symptom expression, but do not examine the distribution of fungicide in above- and belowground plant parts. Published research on irrigation effects most often addresses foliar diseases such as brown patch (Fidanza and Dernoeden 1996; Jiang et al. 1998) and dollar spot (McDonald et al. 2006). Those that involved root diseases addressed irrigation amounts with no comment on fungicide interactions (Davis and Dernoeden 1991; Kackley et al. 1990; Melvin and Vargas 1994), or simply observed no measureable effects of postfungicide irrigation on disease control (Walker 2013). A thorough study by Gardner and Branham (2001) addressed postapplication irrigation effects on the distribution of two fungicides (mefenoxam and propiconazole) over time. They observed no influence of irrigation on propiconazole, but an increased depth of presence of mefenoxam.

The body of evidence that supports tactics to control root disease with fungicides is by no means robust. Current recommendations are founded on inference from casual observations and information generated from tenuous, single-season trials. From a practical perspective, fungicide performance against root diseases is inconsistent at best. A more comprehensive understanding of fungicide distribution in the turf profile, and factors that may influence that distribution, will fortify the existing knowledge base and perhaps contribute to more efficient and effective root disease control. Previous research examined placement and persistence of modern fungicides in the turf profile (Hockemeyer and Latin 2015). This research addresses the influence of postapplication irrigation and a wetting agent application on distribution of fungicides in three turf components.

\section{Materials and Methods}

Field research was conducted at the William H. Daniel Turfgrass Research and Diagnostic Center in West Lafayette, IN on a sward of creeping bentgrass composed of equal mixtures of 'Penncross' and 'Backspin' established in 2008. The site was managed using standard turfgrass maintenance practices for a United States Golf Association (USGA) specification putting green in the Midwest. Root zone substrate was $92.4 \%$ sand, $4.8 \%$ silt, and $2.8 \%$ clay and contained approximately $2.5 \%$ organic matter with a $\mathrm{pH}$ of 7.5 . Grass 
was mowed with a triplex mower to a height of $0.34 \mathrm{~cm}$, six mornings per week, with clippings collected and removed. Irrigation (approximately $0.50 \mathrm{~cm} \mathrm{day}^{-1}$ ) was applied as necessary to prevent moisture stress. Ambient temperature and daily precipitation were measured on site (Davis Instruments Vantage Pro2 Model 6152C). Fertilizer was applied to deliver $134.3 \mathrm{~kg} \mathrm{ha}^{-1}$ year $^{-1}$ nitrogen, $5.4 \mathrm{~kg} \mathrm{ha}^{-1}$ year $^{-1}$ phosphorus, and $111.5 \mathrm{~kg} \mathrm{ha}^{-1}$ year $^{-1}$ potassium. In the previous year (September 2013), the experimental site was core aerified $(1.25 \mathrm{~cm}$ diameter hollow tines spaced at $5 \mathrm{~cm}$ ) and sand topdressed. Beginning on 15 May 2014, fungicides (chlorothalonil and fluazinam) unrelated to those pertinent to this study were applied alternately at 2- to 3-week intervals to protect against natural outbreaks of foliar diseases, such as brown patch (caused by Rhizoctonia solani) and dollar spot (caused by Sclerotinia homoeocarpa). Two runs of the experiment were completed during the 2014 season. Runs 1 and 2 were initiated on 20 May and 23 June, respectively.

Fungicides commonly applied to protect against root diseases were selected for this investigation. Azoxystrobin (Heritage TL; Syngenta Crop Protection) $0.61 \mathrm{~kg}$ a.i. ha ${ }^{-1}$, propiconazole (Banner Maxx; Syngenta Crop Protection) $1.98 \mathrm{~kg}$ a.i. $\mathrm{ha}^{-1}$, pyraclostrobin (Insignia SC; BASF Corporation) $0.55 \mathrm{~kg}$ a.i. ha ${ }^{-1}$, and thiophanatemethyl (Cleary 3336F; Cleary Chemical Corporation) $9.16 \mathrm{~kg}$ a.i. ha ${ }^{-1}$ were applied once as a tank mixture using the high labeled rates provided by the manufacturers. The wetting agent, a modified alkylated polyol (Revolution; Aquatrols, Paulsboro, NJ) $19.5 \mathrm{~kg}$ a.i. $\mathrm{ha}^{-1}$ was applied to designated plots one day prior to the fungicide application. Wetting agent and fungicide applications were applied with a custom-built bicycle wheel boom sprayer. The boom was protected by front and back windshields and was fitted with three flat fan air induction spray nozzle tips (AI9503EVS for the middle, AIUB8503EVS for both sides) (TeeJet Technologies, Wheaton, IL). The sprayer was calibrated to deliver the treatments in a standard volume of 815 liters ha ${ }^{-1}$ water at $275 \mathrm{kPa}$. For treatments receiving postapplication irrigation, the prescribed amount of water was applied manually (watering can) immediately after each plot was sprayed to uniformly deliver a volume of water equivalent to $0.51 \mathrm{~cm}$.

Fungicide characteristics are described in Table 1. The check treatment (fungicide only) included the fungicide tank mix, but received no wetting agent or postapplication irrigation. Treatments were randomized within each of four replications. A 2-m alleyway separated replications. Within each replication, individual plots $(2 \times 1 \mathrm{~m})$ were separated by an untreated 0.75 -m-wide strip of turf to buffer against cross contamination of plots through fungicide drift.

Samples were collected from the center region of each plot on 0,3 , $7,10,14,21,28,35$, and 42 days following the fungicide application, with day 0 samples collected after deposits were dry, 4 to $6 \mathrm{~h}$ posttreatment. For the establishment of baseline fungicide residues present at the site, samples collected from the nonfungicide treated check plots on day 0 were used as representative samples for each replication in run 1 . In run 2 , a more comprehensive baseline was

Table 1. Characteristics of fungicides used to examine effects of wetting agent and postapplication irrigation on fungicide distribution in the turf profile

\begin{tabular}{|c|c|c|c|c|}
\hline Fungicide & Product & $\begin{array}{c}\text { Application rate } \\
\left(\mathrm{kg}^{2} \text { a.i. ha- }\right.\end{array}$ & $\mathrm{K}_{\mathrm{oc}}{ }^{\mathrm{a}}$ & $\begin{array}{l}\text { Water solubility } \\
\quad(\mathrm{ml} \mathrm{liter}-1)\end{array}$ \\
\hline Azoxystrobin & $\begin{array}{l}\text { Heritage } \\
\text { TL }\end{array}$ & 0.61 & 581 & 6 \\
\hline Propiconazole & $\begin{array}{r}\text { Banner } \\
\text { Maxx }\end{array}$ & 1.98 & 656 & 100 \\
\hline Pyraclostrobin & $\begin{array}{l}\text { Insignia } \\
\text { SC }\end{array}$ & 0.55 & 9,300 & 20 \\
\hline $\begin{array}{l}\text { Thiophanate- } \\
\text { methyl }\end{array}$ & $\begin{array}{l}\text { Cleary } \\
3336 \mathrm{~F}\end{array}$ & 9.16 & 225 & 25 \\
\hline Carbendazim $^{\mathrm{b}}$ & & & 223 & 8 \\
\hline
\end{tabular}

${ }^{\text {a }}$ Soil Organic Carbon-Water Partitioning Coefficient.

${ }^{\mathrm{b}}$ Carbendazim was not applied as a product, but it is a metabolite of thiophanate-methyl. established by sampling all plots one day prior to the fungicide application. A soil probe $(1.9 \mathrm{~cm}$ diameter) was used to collect samples to a depth of $3.8 \mathrm{~cm}$. A standard single-edge razor blade was used to partition each sample core into two sections, separating the verdure/ thatch (upper $1.5 \mathrm{~cm})$ from soil $(2.3 \mathrm{~cm})$. It was impossible to separate thatch (a loose matrix of organic matter, including dead and living roots) from verdure; therefore, they were treated as a single component in the profile. Separated cores were placed in $50 \mathrm{ml}$ polypropylene conical tubes, refrigerated on site, and then transported to a freezer $\left(-80^{\circ} \mathrm{C}\right)$ until they could be processed for fungicide residue extraction and quantitative analysis.

The soil core sections were dried (Yamato DKN600 Mechanical Convection Oven, Santa Clara, CA) at $43^{\circ} \mathrm{C}$ for $24 \mathrm{~h}$ to facilitate separation of roots from soil cores. The fibrous creeping bentgrass roots were manually separated from soil and transferred into $1.5-\mathrm{ml}$ micro centrifuge tubes. Soil from each core was then returned to the $50 \mathrm{ml}$ polypropylene conical tubes. Root and soil component samples were

Table 2. $P$ values for each fungicide from analysis of variance on $\log$ transformed fungicide residue data in the verdure/thatch component

\begin{tabular}{lcllllr}
\hline & & \multicolumn{5}{c}{ Fungicide $^{\mathbf{a}}$} \\
\cline { 3 - 7 } Source & df & AZX & CBZ & PPZ & PYR & \multicolumn{1}{c}{ TM } \\
\hline Run & 1 & 0.0058 & 0.0262 & 0.0210 & 0.0114 & $<0.0001$ \\
Replication & 3 & 0.1810 & 0.0556 & 0.6333 & 0.5855 & 0.0140 \\
Irrigation & 1 & 0.7113 & 0.0542 & 0.2362 & 0.2578 & $<0.0001$ \\
Wetting agent & 1 & 0.3528 & 0.7577 & 0.7096 & 0.9079 & 0.1079 \\
Irrigation*wetting & 1 & 0.8464 & 0.8030 & 0.2663 & 0.3417 & 0.6697 \\
$\quad$ agent & & & & & & \\
Sample day & 8 & $<0.0001$ & $<0.0001$ & $<0.0001$ & $<0.0001$ & $<0.0001$ \\
\hline
\end{tabular}

${ }^{a}$ Fungicide abbreviations are as follows: $\mathrm{AZX}=$ azoxystrobin, $\mathrm{CBZ}=$ carbendazim, $\mathrm{PPZ}=$ propiconazole, $\mathrm{PYR}=$ pyraclostrobin, $\mathrm{TM}=$ thiophanatemethyl.

Table 3. $P$ values for each fungicide from analysis of variance on $\log$ transformed fungicide residue data in the root component

\begin{tabular}{lcrrrrr}
\hline & & \multicolumn{5}{c}{ Fungicide $^{\mathbf{a}}$} \\
\cline { 3 - 7 } Source & df & AZX & \multicolumn{1}{c}{ CBZ } & \multicolumn{1}{c}{ PPZ } & \multicolumn{1}{c}{ PYR } & \multicolumn{1}{c}{ TM } \\
\hline Run & 1 & 0.9835 & 0.3683 & 0.8058 & 0.8939 & $<0.0001$ \\
Replication & 3 & 0.0618 & 0.7630 & 0.1132 & 0.0001 & 0.0221 \\
Irrigation & 1 & $<0.0001$ & $<0.0001$ & $<0.0001$ & $<0.0001$ & $<0.0001$ \\
Wetting agent & 1 & 0.1496 & 0.0242 & 0.0447 & 0.2254 & 0.1620 \\
Irrigation*wetting & 1 & 0.4761 & 0.2040 & 0.3955 & 0.3200 & 0.3804 \\
$\quad$ agent & & & & & & \\
Sample day & 8 & $<0.0001$ & $<0.0001$ & $<0.0001$ & $<0.0001$ & $<0.0001$ \\
\hline
\end{tabular}

${ }^{a}$ Fungicide abbreviations are as follows: $\mathrm{AZX}=$ azoxystrobin, $\mathrm{CBZ}=$ carbendazim, $\mathrm{PPZ}=$ propiconazole, $\mathrm{PYR}=$ pyraclostrobin, $\mathrm{TM}=$ thiophanatemethyl.

Table 4. $P$ values for each fungicide from analysis of variance on $\log$ transformed fungicide residue data in the soil component

\begin{tabular}{lcrrrrr}
\hline & & \multicolumn{5}{c}{ Fungicide $^{\mathbf{a}}$} \\
\cline { 3 - 7 } Source & df & AZX & \multicolumn{1}{c}{ CBZ } & \multicolumn{1}{c}{ PPZ } & \multicolumn{1}{c}{ PYR } & \multicolumn{1}{c}{ TM } \\
\hline Run & 1 & 0.0182 & 0.2482 & 0.0011 & 0.0768 & $<0.0001$ \\
Replication & 3 & 0.1437 & 0.9303 & 0.0590 & $<0.0001$ & 0.0596 \\
Irrigation & 1 & $<0.0001$ & $<0.0001$ & $<0.0001$ & $<0.0001$ & $<0.0001$ \\
Wetting agent & 1 & 0.0345 & 0.0038 & 0.0003 & 0.2089 & 0.0238 \\
Irrigation*wetting & 1 & 0.5363 & 0.1231 & 0.2822 & 0.3948 & 0.0655 \\
$\quad$ agent & & & & & & \\
Sample day & 8 & $<0.0001$ & $<0.0001$ & $<0.0001$ & $<0.0001$ & $<0.0001$ \\
\hline
\end{tabular}

${ }^{a}$ Fungicide abbreviations are as follows: $\mathrm{AZX}=$ azoxystrobin, $\mathrm{CBZ}=$ carben dazim, $\mathrm{PPZ}=$ propiconazole, $\mathrm{PYR}=$ pyraclostrobin, $\mathrm{TM}=$ thiophanatemethyl. 
stored at $-80^{\circ} \mathrm{C}$ until the fungicide residue extraction process was initiated. Dry weights were recorded for all component samples.

The QuEChERS method, developed by Anastassiades et al. (2003) and modified by Daniels and Latin (2013) and Hockemeyer and Latin (2015), was used to extract fungicide residues from verdure/ thatch and root components. Each verdure/thatch sample was transferred into a 7-ml homogenizer tube prefilled with $2.8 \mathrm{~mm}$ ceramic beads (Cayman Chemical, Ann Arbor, MI). Homogenization was performed in a volume of $4 \mathrm{ml}$ acetonitrile and water $80 / 20 \mathrm{vol} / \mathrm{vol}$ (Precellys 24-dual, Bertin Technologies) at 6,500 rpm for three $15 \mathrm{~s}$ cycles. Homogenized samples were transferred to $15 \mathrm{ml}$ polypropylene conical tubes where $6 \mathrm{ml}$ acetonitrile and water $(80 / 20$ $\mathrm{vol} / \mathrm{vol})$ were added. Magnesium sulfate $(300 \mathrm{mg}$ ) and sodium acetate $(75 \mathrm{mg})$ were added to enable the separation of water from the organic solvent. An internal standard of $10 \mu \mathrm{l}$ of metconazole $\left(10 \mathrm{mg} \mathrm{ml}^{-1}\right)$ was also added for quality control. Samples were
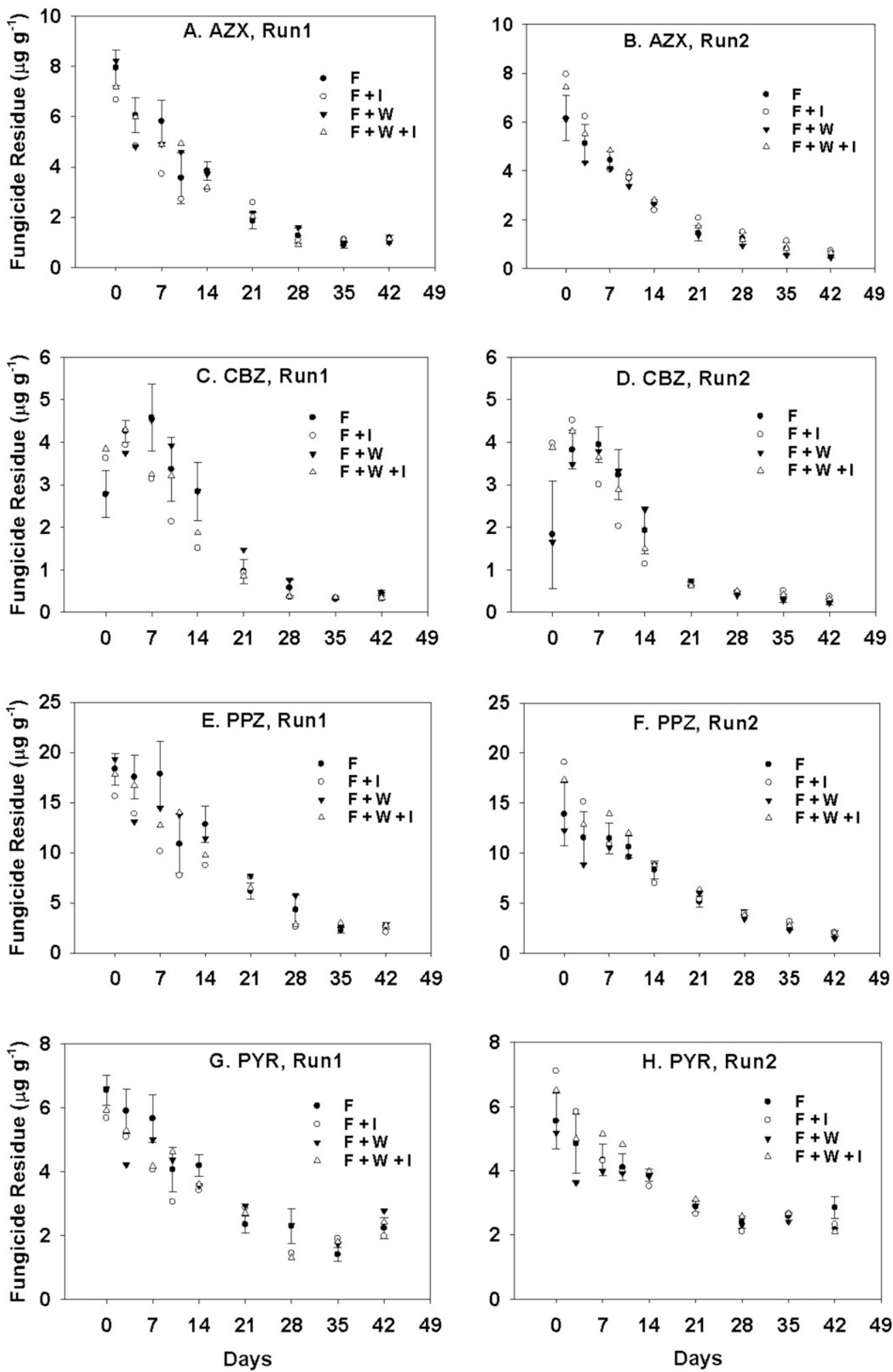

Fig. 1. Temporal distribution of fungicide residues in the verdure/thatch component associated with four treatments, including fungicide only $(F)$, fungicide + irrigation $(F+I)$, fungicide + wetting agent $(F+W)$, and fungicide + wetting agent + irrigation $(F+W+I)$ for two experimental runs. The four fungicides are azoxystrobin (AZX), carbendazim (CBZ), propiconazole (PPZ), and pyraclostrobin (PYR). 
shaken vigorously for $1 \mathrm{~min}$, centrifuged for $5 \mathrm{~min}$ at 3,000 rpm, and then transferred into $15-\mathrm{ml}$ dispersive-solid phase extraction tubes (Agilent Technologies) containing $855 \mathrm{mg}$ magnesium sulfate, $150 \mathrm{mg}$ primary and secondary amine (PSA), and $45 \mathrm{mg}$ graphitized carbon black (GCB). Supernatant $(1 \mathrm{ml})$ was then transferred into $1.5-\mathrm{ml}$ micro centrifuge tubes and stored at $-80^{\circ} \mathrm{C}$ until analysis.

The extraction process for roots was similar with samples transferred into $7 \mathrm{ml}$ homogenizer tubes prefilled with $2.8 \mathrm{~mm}$ ceramic beads and homogenized at 6,500 rpm for two 15 s cycles. Magnesium sulfate $(105 \mathrm{mg})$ and sodium acetate $(25 \mathrm{mg})$ were added along with the internal standard of $10 \mu \mathrm{l}$ of metconazole $\left(10 \mathrm{mg} \mathrm{ml}^{-1}\right)$. Samples were shaken vigorously for $1 \mathrm{~min}$ and then centrifuged at $3,000 \mathrm{rpm}$ for $5 \mathrm{~min}$. Supernatant $(1 \mathrm{ml})$ was then transferred to $1.5-\mathrm{ml}$ micro centrifuge tubes and stored at $-80^{\circ} \mathrm{C}$ until analysis. Preliminary tests showed that a simplified process for extraction of fungicide from soil with some modifications could also be applied to the
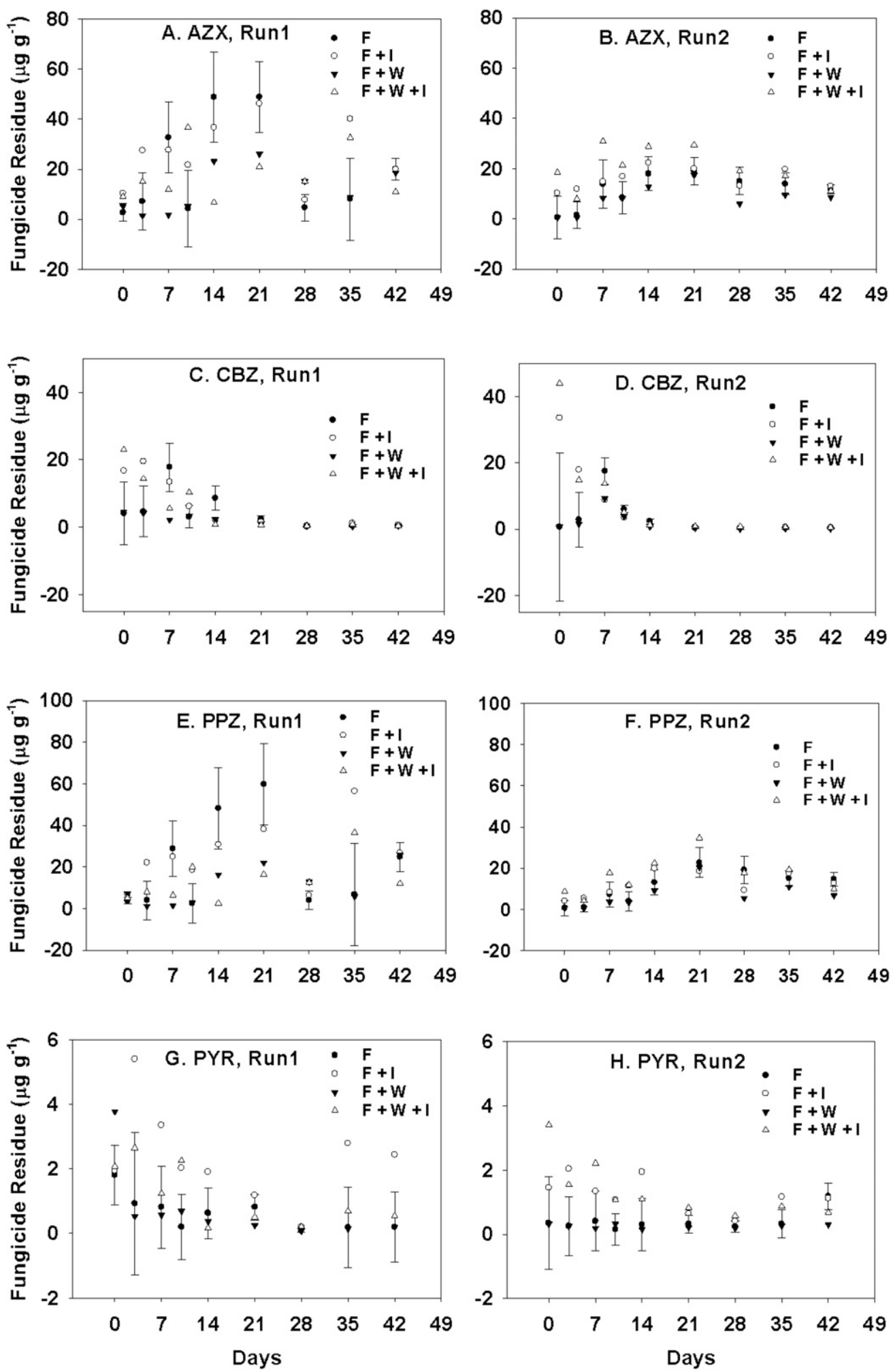

Fig. 2. Temporal distribution of fungicide residues in the root component associated with four treatments, including fungicide only $(F)$, fungicide + irrigation $(F+I)$, fungicide + wetting agent $(F+W)$, and fungicide + wetting agent + irrigation $(F+W+I)$ for two experimental runs. The four fungicides are azoxystrobin (AZX), carbendazim (CBZ), propiconazole (PPZ), and pyraclostrobin (PYR). 
extraction from root tissue and still provide reliable results (Pinto et al. 2010).

Extraction of residues from soil samples was performed by adding volume of $10 \mathrm{ml}$ acetonitrile and water $80 / 20 \mathrm{vol} / \mathrm{vol}$ to each soil sample and vigorously shaking for $1 \mathrm{~min}$. Magnesium sulfate $667 \mathrm{mg}$ was added along with the internal standard of $10 \mu \mathrm{l}$ of metconazole $\left(10 \mathrm{mg} \mathrm{ml}^{-1}\right)$. Samples were shaken vigorously for $1 \mathrm{~min}$, centrifuged at 3,000 rpm for $5 \mathrm{~min}$, and $1 \mathrm{ml}$ of supernatant was transferred into $1.5-\mathrm{ml}$ micro centrifuge tubes for storage at $-80^{\circ} \mathrm{C}$ until analysis.

Residues were quantified using liquid chromatography-mass spectrometry/mass spectrometry (LC-MS/MS). The Agilent 1200 Series Rapid Resolution liquid chromatography system was utilized for detection of fungicides, comprising of a vacuum degasser, a well plate autosampler, and a binary pumping device coupled to the Agilent 6460 Triple Quad (QQQ) mass spectrometer (Agilent
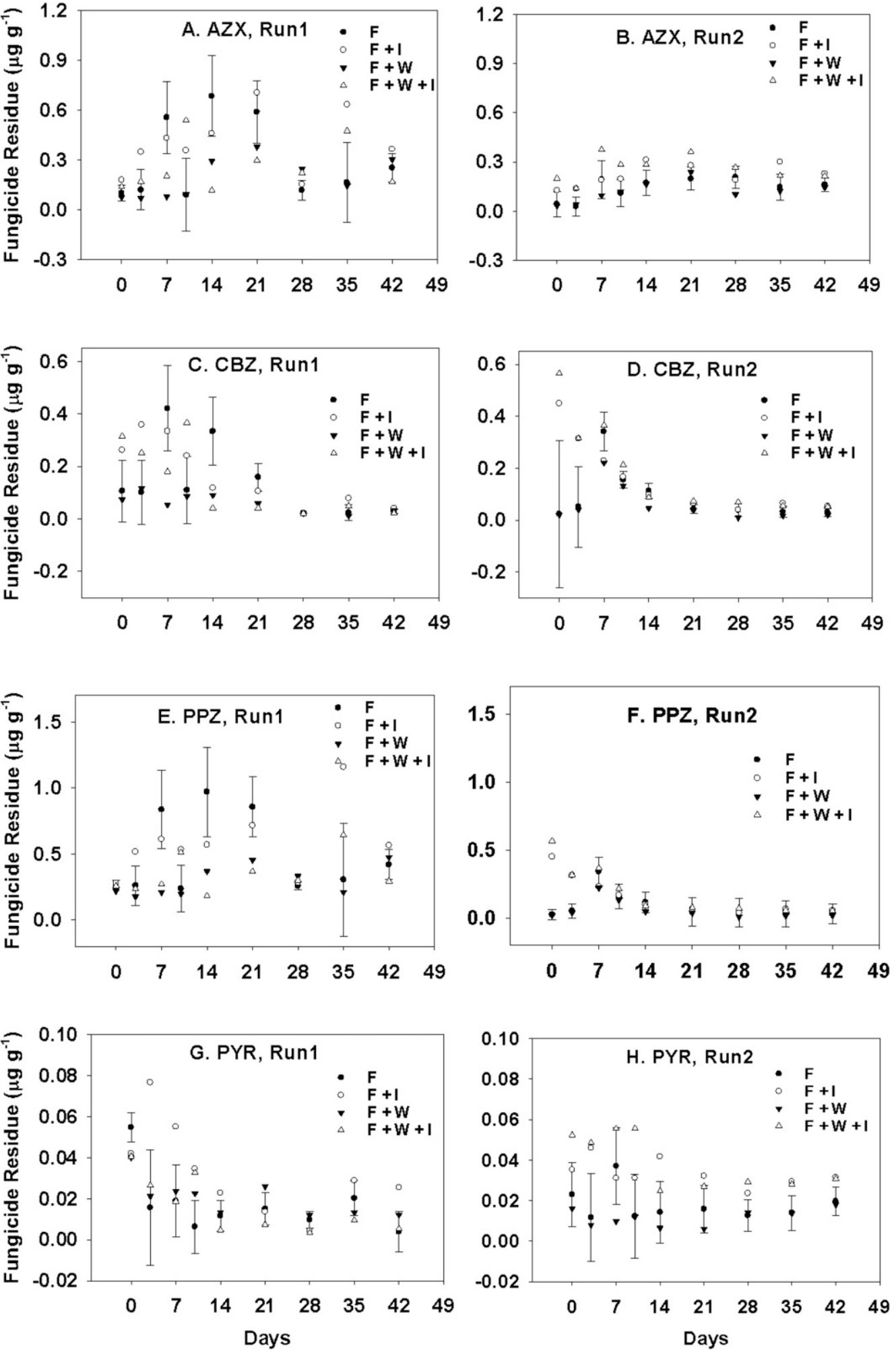

Fig. 3. Temporal distribution of fungicide residues in the soil component associated with four treatments, including fungicide only $(F)$, fungicide + irrigation $(F+I)$, fungicide + wetting agent $(F+W)$, and fungicide + wetting agent + irrigation $(F+W+I)$ for two experimental runs. The four fungicides are azoxystrobin (AZX), carbendazim (CBZ), propiconazole (PPZ), and pyraclostrobin (PYR). 
Technologies). Fungicide separation utilized a reversed-phase Zorbax SB-Phenyl column $(4.6 \times 150 \mathrm{~mm}, 5 \mu \mathrm{m})$ obtained from Agilent. Machine protocols were same as those used by Hockemeyer and Latin (2015). Four fungicides and the fungitoxic metabolite of thiophanate-methyl, methyl 2-benzimidazole carbamate (MBC or carbendazim), were included in the analysis. Carbendazim was included because the degradation of thiophanate-methyl occurs rapidly into the metabolite compound (Fleeker et al. 1974). Analytical standards for each fungicide or fungitoxic metabolite-azoxystrobin (99.4\%), carbendazim (99.2\%), pyraclostrobin (99.9\%), propiconazole $(99.2 \%)$, thiophanate-methyl $(99.3 \%)$, and metconazole (99.5\%) — were obtained from Sigma-Aldrich (St. Louis, MO). Stock solutions of $10 \mathrm{mg} \mathrm{ml}^{-1}$ were prepared in acetonitrile for all standards with the exception of carbendazim, prepared in acetone at $0.3 \mathrm{mg} \mathrm{ml}^{-1}$. For instrument calibration, standard solution mixtures of azoxystrobin, carbendazim, propiconazole, pyraclostrobin, and thiophanate-methyl were serial diluted in acetonitrile and stored at $-20^{\circ} \mathrm{C}$

Results from the analysis were determined using the Agilent MassHunter Quantitative Analysis (version B01.04) software. Data were normalized per gram dry weight of component sampled, and analysis of variance (PROC GLM) was performed on 864 observations and 5 variables (turf component, replication, run, treatment, and sampling day) using SAS 9.4. Also, orthogonal contrasts were constructed to compare each of the three treatments (irrigation, wetting agent, irrigation + wetting agent) with the fungicide only treatment. Data were analyzed by component (verdure/thatch, roots, and soil) and run (runs 1 and 2), and pooled through sampling dates. For orthogonal contrasts that indicated significant treatment differences, the Waller-Duncan $k$-ratio $t$ test was used to perform multiple comparison of treatments. Furthermore, PROC GENMOD was used to generate confidence bands (95\%) around mean daily estimates of each fungicide.

\section{Results}

Analysis of variance was performed on the five compounds (azoxystrobin, carbendazim, propiconazole, pyraclostrobin, and thiophanate-methyl), and for each component, verdure/thatch, root, and soil, respectively (Tables 2, 3, and 4). A log transformation was applied to reduce skewness of data and improve normality. The experimental run was significant for all compounds in verdure/thatch, but not for all in root and soil component. However, since the two runs were separated in time and were exposed to different environmental conditions, figures were created separately for each run. Fungicide residues on sample dates were treated independently due to no significant autocorrelation of transformed data. Confidence bands (95\%) were generated for each treatment and each fungicide during the 42 days of sampling for untransformed data (Figs. 1 to 3). Treatment-F+I (fungicide plus irrigation), $\mathrm{F}+\mathrm{W}$ (fungicide plus wetting agent), and $\mathrm{F}+\mathrm{I}+\mathrm{W}$ (fungicide plus irrigation plus wetting agent) - effects were considered significant if their means were positioned outside the confidence band of the check treatment $\mathrm{F}$ (fungicide only).

The most consistent result was the significant sampling day effect that was observed for all fungicides, over both runs, and in all three components (Tables 2, 3, and 4). Treatment effects differed among components and were addressed individually. Carbendazim residues were used as a proxy for thiophanate-methyl in analyses of treatment effects in each turf component addressed below. Thiophanate-methyl was depleted quickly in all components and in both runs. In almost all cases, thiophanate-methyl residues dwindled to the limits of instrument detection within 7 days of application. Results involving thiophanate-methyl and carbendazim were similar over the first 7 days, but carbendazim residues were detected over most of the experimental period in both runs. Carbendazim is the primary natural degradation product of thiophanate-methyl, and is a fungi-toxic metabolite. Precedent supports using carbendazim as a representative of thiophanatemethyl and other benzimidazole fungicides (Anastassiades and Schwack 1998).
Treatment comparisons in turf components. In the verdure/ thatch component, there was a significant effect of sampling day, i.e., residues were depleted over time. Fungicide residues were generally not affected by irrigation and wetting agent treatments, as evidenced by mostly high $P$ values in Table 2 . Residue depletion in the verdure/thatch component over the entire sampling period for both runs is detailed in Figure 1A to $\mathrm{H}$. There appear to be no consistent patterns that describe treatment effects on any of the fungicides in both runs. In fact, in most samples and on most dates, treatment means for $\mathrm{F}+\mathrm{I}, \mathrm{F}+\mathrm{W}$, and $\mathrm{F}+\mathrm{I}+\mathrm{W}$ were positioned within the $95 \%$ confidence bands around the fungicide-only $(\mathrm{F})$ check treatment.

In the root component, sampling day and irrigation effects were significant for all fungicides (Table 3). Effects of wetting agent were significant for carbendazim and propiconazole. There were no significant effects for the irrigation plus wetting agent treatment for any fungicide. Inspection of individual sampling date results (Fig. 2A to $\mathrm{H}$ ) shows generally higher fungicide residue levels associated with the irrigation $(\mathrm{F}+\mathrm{I})$ treatment compared with the fungicide-only $(\mathrm{F})$ treatment. Irrigation never resulted in a comparative decrease in fungicide residues in root samples. For the $\mathrm{F}+\mathrm{W}$ treatment, an increase in fungicide residue in roots was observed in only one case (pyraclostrobin, sample day 0 , run 1, Fig. 2G). In all other cases, where significant differences were measured, wetting agent $(\mathrm{F}+\mathrm{W})$ resulted in a decrease of fungicide residue levels in roots. Residues quantified over individual sample dates differed with fungicide in the $\mathrm{F}+\mathrm{I}+\mathrm{W}$ treatment. For example, for pyraclostrobin (Fig. 2G and H), residues in roots were never lower and often higher compared with the fungicide-only check. However, for azoxystrobin and propiconazole, residue amounts differed between runs (Fig. 2A and B and Fig. 2E and F), with no consistent pattern.

Results for the soil and root components were similar. Sampling day and irrigation effects were significant across all fungicides (Table 4). Wetting agent was significant for azoxystrobin, carbendazim, and propiconazole. Inspection of sampling day data (Fig. 3) shows that on most sample dates, residues associated with the irrigation treatment $(\mathrm{F}+\mathrm{I})$ were within the margin of error around the fungicide-only check $(\mathrm{F})$. Where significant differences did occur, postapplication irrigation $(\mathrm{F}+\mathrm{I})$ resulted in an increase in residues in the soil component (Fig. 3A to $\mathrm{H}$ ). In all but one case (azoxystrobin, run 1, day 28, Fig. 3A), the F+W treatment either had no effect or resulted in a comparative reduction in fungicide residue in soil.

Table 5. Orthogonal contrast comparison of treatment effects (compared with fungicide only treatment) on the distribution of five fungicides in three components and two runs pooled by sampling dates

\begin{tabular}{|c|c|c|c|c|c|c|c|}
\hline \multirow[b]{2}{*}{ Component } & \multirow[b]{2}{*}{ Fungicide $^{\mathbf{a}}$} & \multicolumn{3}{|c|}{ Run 1} & \multicolumn{3}{|c|}{ Run 2} \\
\hline & & $I^{\mathbf{b}}$ & $\mathbf{W}^{\mathbf{c}}$ & $I+W$ & I & $\mathbf{W}$ & $\mathbf{I}+\mathbf{W}$ \\
\hline \multirow[t]{5}{*}{ Verdure/thatch } & AZX & $\mathrm{NS}^{\mathrm{d}}$ & NS & NS & + & - & NS \\
\hline & CBZ & NS & NS & - & NS & NS & NS \\
\hline & PPZ & - & NS & NS & NS & - & NS \\
\hline & PYR & NS & NS & NS & NS & NS & NS \\
\hline & $\mathrm{TM}$ & - & NS & - & - & NS & - \\
\hline \multirow[t]{5}{*}{ Root } & AZX & + & NS & NS & + & NS & + \\
\hline & CBZ & NS & NS & NS & + & NS & + \\
\hline & PPZ & + & NS & NS & + & - & + \\
\hline & PYR & + & NS & + & + & NS & + \\
\hline & $\mathrm{TM}$ & NS & NS & NS & + & NS & + \\
\hline \multirow[t]{5}{*}{ Soil } & AZX & + & NS & NS & + & NS & + \\
\hline & CBZ & NS & - & NS & + & - & + \\
\hline & PPZ & NS & - & NS & + & - & + \\
\hline & PYR & + & NS & NS & + & NS & + \\
\hline & $\mathrm{TM}$ & NS & - & NS & + & - & + \\
\hline
\end{tabular}

a $\mathrm{AZX}=$ azoxystrobin, $\mathrm{CBZ}=$ carbendazim, $\mathrm{PPZ}=$ propiconazole, $\mathrm{PYR}=$ pyraclostrobin, $\mathrm{TM}=$ thiophanate-methyl.

${ }^{\mathrm{b}} \mathrm{I}=$ irrigation.

${ }^{\mathrm{c}} \mathrm{W}=$ wetting agent.

${ }^{\mathrm{d}} \mathrm{NS}=$ no significant difference from the fungicide only treatment. $+=$ increased residues compared with the fungicide only treatment. - = decreased residues compared with the fungicide only treatment. 
Fungicide residues in soil associated with the $\mathrm{F}+\mathrm{I}+\mathrm{W}$ treatment differed among fungicides, but on most sampling dates residues were within the confidence bands around means for the fungicide-only check.

\section{Discussion}

This research described the influence of a single wetting agent treatment, applied according to label instructions, one day prior to the fungicide sprays and postfungicide irrigation on fungicide distribution. Given that the wetting agent is designed to improve water infiltration, it was hypothesized that it would increase fungicide distribution in roots and soil below the thatch layer. These results do not support that position. Table 5 summarizes comparisons of treatment effects for each fungicide, in each component, and over both runs based on orthogonal contrasts. In no case did wetting agent improve (a few cases decrease) the distribution of fungicide in the turf profile. Even when the wetting agent was combined with posttreatment irrigation, patterns of fungicide distribution closely resembled those of the irrigation treatment. Conclusions are reinforced by comparisons of treatment effects illustrated in nonnormalized data. Figure 4 shows total amounts of fungicide (in this example azoxystrobin) in each component over the experimental period in run 1. It is representative of a common pattern observed for all fungicides in both runs. Stacked plots for the F treatment (Fig. 4A) were nearly identical to the $\mathrm{F}+\mathrm{W}$ treatment (Fig. 4C). Likewise, Figure 4B (F+I) is barely distinguishable from Figure $4 \mathrm{D}(\mathrm{F}+\mathrm{I}+\mathrm{W})$. The effect of wetting agent applied in this manner on distribution of fungicide in the turf profile was negligible. Although wetting agents have been effective in improving turf quality under stressful environmental conditions, particularly on sand-based greens (Kostka et al. 1997), we found no evidence to corroborate the notion that wetting agent treatment prior to fungicide application will facilitate distribution of

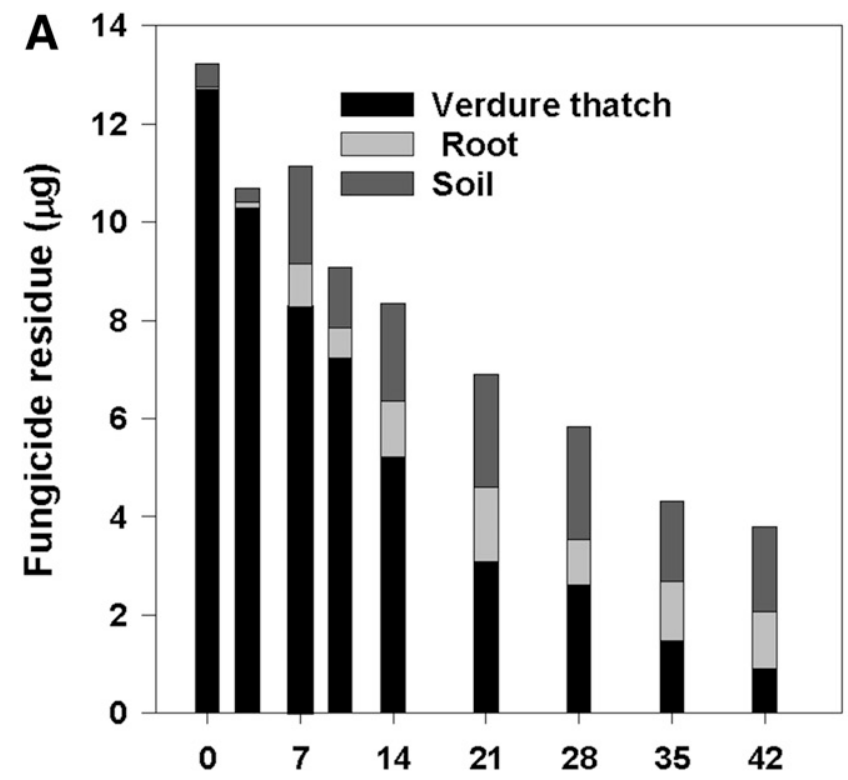

Days after fungicide application

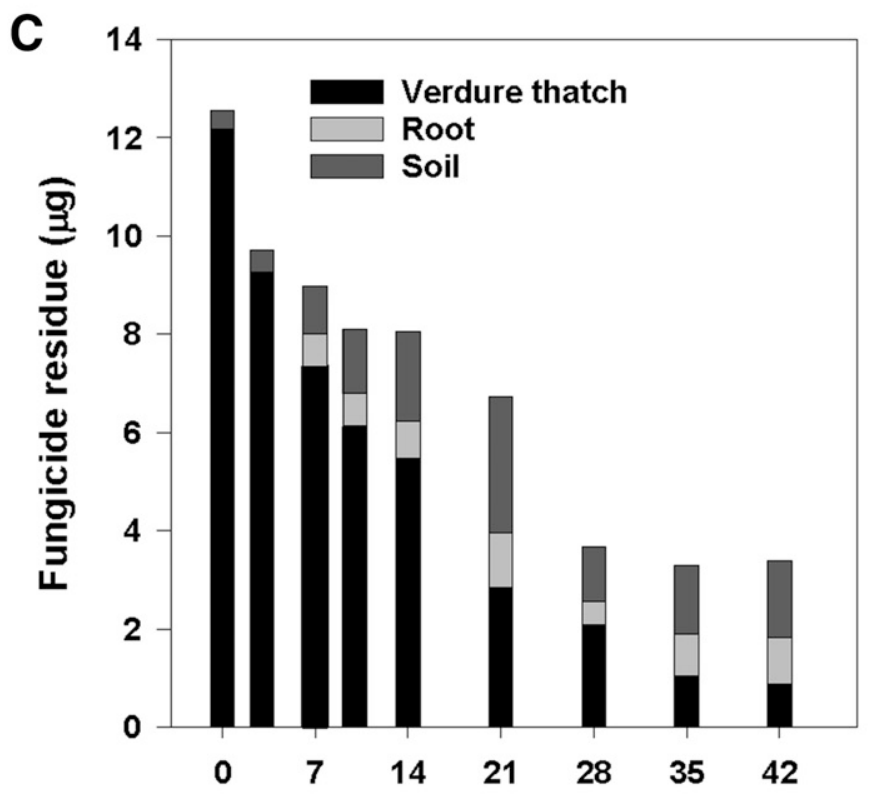

Days after fungicide application

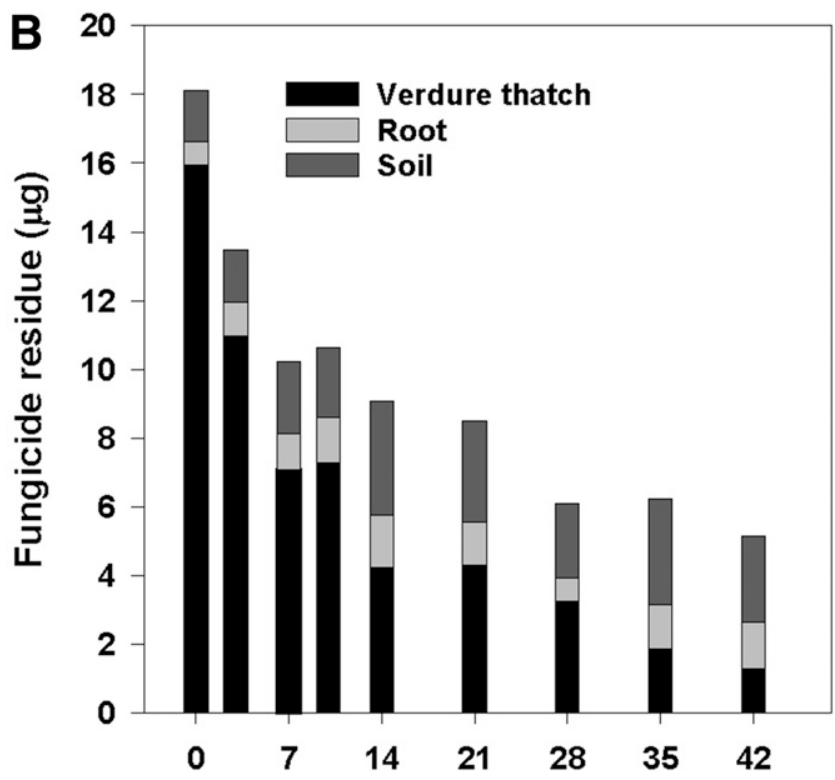

Days after fungicide application

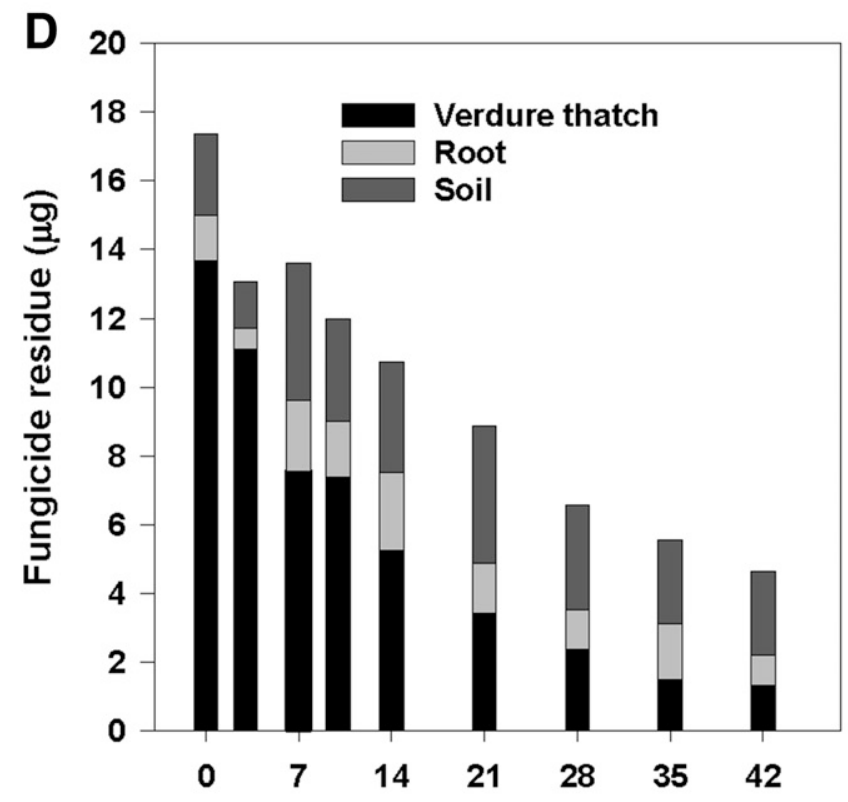

Days after fungicide application

Fig. 4. Stacked plots showing total azoxystrobin residues distributed in three turf components, verdure/thatch (C1), root (C2), and soil (C3) in run 1. The four treatments included A, fungicide only, B, fungicide + irrigation, $\mathbf{C}$, fungicide + wetting agent, and D, fungicide + irrigation + wetting agent. 
fungicide below ground level. In comparable research, Cisar and Snyder (2000) reported no effect of a nonionic wetting agent on fenamiphos residues detected in thatch and soil, regardless of tank mixing the compounds, or applying them in two separate applications (wetting agent first). Pesticide movement is largely governed by attributes involving solubility and adsorption to organic matter. The improved infiltration afforded by the wetting agent may not be sufficient to compensate for relatively low solubility and moderate-high binding attributes of fungicides applied in this research. Additional research will improve understanding of wetting agent effects after multiple applications, or when tank mixed with turf fungicides.

Irrigation effects in the verdure/thatch component were rarely observed beyond 14 days after treatment and varied between runs. Depletion factors such as microbial degradation and removal of deposit (mowing, irrigation, and precipitation) likely reduced residues to such low levels that any treatment differences were negligible. Previous research supports this result and demonstrates that modern fungicides were depleted from verdure within 10 days of application (Daniels and Latin 2013). For root and soil components, irrigation effects differed between runs (Table 5). Levels of detected residues were greater in the second run. Environmental conditions during each run were different, and perhaps played a role (Fig. 5). Over the first 7 days of the experiment in run 1, natural precipitation $(0.28 \mathrm{~cm})$ occurred 2 days after fungicide application, and was followed by five consecutive days of irrigation at approximately $0.50 \mathrm{~cm} \mathrm{day}^{-1}$. In run 2, precipitation occurred on the 3 days following the fungicide application $(1.26 \mathrm{~cm}$ total, with $0.30 \mathrm{~cm}$ the evening following the fungicide spray). Plots also received irrigation (approximately $0.50 \mathrm{~cm} \mathrm{day}^{-1}$ ) on day 5 and day 7 . It is possible that
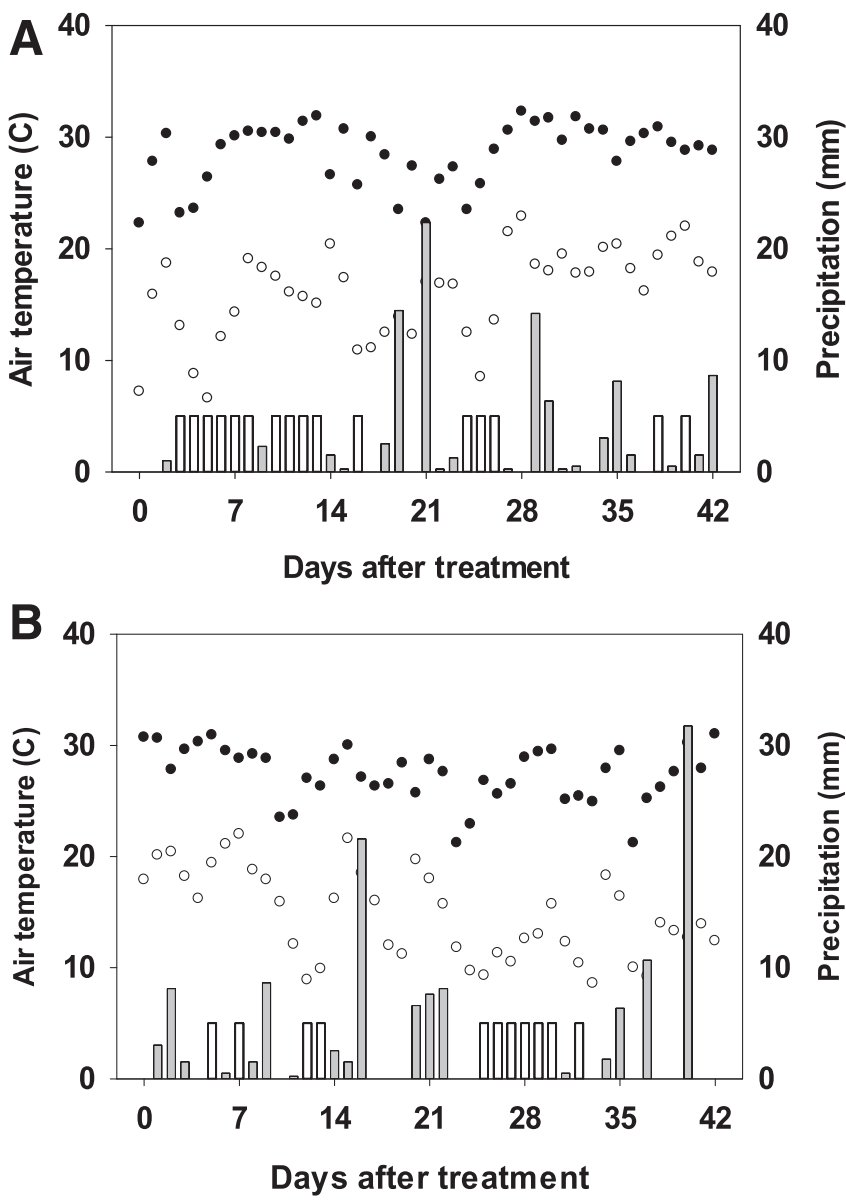

Fig. 5. Daily temperature and precipitation during run 1 (A) and run 2 (B). Symbols represent maximum daily temperature (black circles), minimum daily temperature (white circles), natural precipitation (gray columns), and supplemental irrigation (white columns). precipitation soon after the fungicide treatment rinsed additional fungicide through the thatch layer, which was then detected in roots and soil during quantitative analysis.

Fungicide distribution and persistence in turf has been the subject of previous research. Daniels and Latin (2013) showed that presence of fungi-toxic concentrations of several fungicides in creeping bentgrass verdure was very brief ( 7 to 14 days). Hockemeyer and Latin (2015) showed that among the three components of turf, fungicide remains mostly in the verdure/thatch, especially for compounds with high $\mathrm{K}_{\mathrm{oc}}$ values. Wu et al. (2002) suggested that only the most soluble fungicides (e.g., metalaxyl, water solubility $=26,000 \mathrm{mg} \mathrm{liter}^{-1}$ ) would filter below the top $2 \mathrm{~cm}$ of the turf (essentially the verdure/ thatch). Gardner and Branham (2001) also showed that only the highly soluble mefenoxam (similar to metalaxyl) was influenced by irrigation and was detected below the thatch layer. Similarly, Schumann et al. (2000) reported negligible fungicide residues below the thatch layer despite $1.3 \mathrm{~cm}$ irrigation immediately following fungicide application. Given the relatively low solubility and high adsorption coefficients of fungicides tested here (Table 1), limited movement below the highly organic thatch layer is not unexpected.

This is the first published paper documenting effects of common turf management practices-wetting agent treatment prior to fungicide sprays and postfungicide irrigation treatment - on distribution of fungicides in the turf profile. Using modern instrumentation to accurately detect and quantify fungicide residues, these results replace anecdotal information and hearsay and provide turf managers with evidence that even in a sand-based turf profile, the influence of wetting agent on fungicide distribution is marginal, and irrigation effects may be subject to environmental variability. Additional research to examine effects of other management practices will improve understanding of fungicide distribution and, eventually, how they contribute to disease control on golf course turf.

\section{Acknowledgments}

The authors wish to recognize Amber Jannasch for assistance with quantitative analysis, Schafer Knostmann and Tim Sibicky for collection and processing of turf samples, and Wutao Wei for assistance with statistical analysis.

\section{Literature Cited}

Anastassiades, M., Lehotay, S. J., Stajnbaher, D., and Schenck, F. J. 2003. Fast and easy multiresidue method employing acetonitrile extraction/partitioning and dispersive solid-phase extraction for the determination of pesticide residues in produce. J. AOAC Int. 86:412-431.

Anastassiades, M., and Schwack, W. 1998. Analysis of carbendazim, benomyl, thiophanate methyl, and 2,4-dichlorophenoxyacetic acid in fruits and vegetables after supercritical fluid extraction. J. Chromatogr. 825:45-54.

Cisar, J. L., and Snyder, G. H. 2000. Pesticides in percolate, thatch, soil, and clippings and approaches to reduce fenamiphos and fenamiphos metabolite leaching. Pages 106-126 in: Fate and Management of Turfgrass Chemicals. J. M. Clark and M. P. Kenna, eds. American Chemical Society, Washington, DC.

Daniels, J., and Latin, R. 2013. Residual efficacy of fungicides for controlling brown patch on creeping bentgrass fairways. Plant Dis. 97:1620-1625.

Davis, D. B., and Dernoeden, P. H. 1991. Summer patch and Kentucky bluegrass quality as influenced by cultural practices. Agron. J. 83:670-677.

Dernoeden, P. H., Kaminski, J. E., and Krouse, J. M. 2002. Dollar spot control with fungicides, nitrogen sources, and a wetting agent, 2001. Fungicide Nematic. Tests 58:T036.

Earlywine, D., and Miller, G. L. 2015. Evaluation of multiple fungicides in combination with a wetting agent for spring dead spot control on bermudagrass, 2013-2014. Plant Dis. Manag. Rep. 9:T018.

Fidanza, M. A., and Dernoeden, P. H. 1996. Brown patch severity in perennial ryegrass as influenced by irrigation, fungicide, and fertilizers. Crop Sci. 36: $1631-1638$.

Fidanza, M. A., and McDonald, S. J. 2007. Injection of a fungicide and a soil surfactant for fairy ring control in perennial ryegrass, 2006. Plant Dis. Manag. Rep. 3:T069.

Fidanza, M. A., Sanford, D. L., Wetzel, H., Jr., and Nattle, J. S. 2002. Evaluation of fungicides, a soil wetting agent, and cultural practices for curative fairy ring control, 2001. Fungicide Nematic. Tests 58:T036.

Fleeker, J. R., Lacy, H. M., Schultz, I. R., and Houkom, E. C. 1974. Persistence and metabolism of thiophanate-methyl in soil. J. Agric. Food Chem. 22:592-595.

Gardner, D. S., and Branham, B. E. 2001. Effect of turfgrass cover and irrigation on soil mobility and dissipation of mefenoxam and propiconazole. J. Environ. Qual. 30:1612-1618.

Hockemeyer, K. R., and Latin, R. 2015. Spatial and temporal distribution of fungicides applied to creeping bentgrass. J. Environ. Qual. 44:841. 
Hsu, F., and Kleier, D. A. 1996. Phloem mobility of xenobiotics VIII. A short review. J. Exp. Bot. 47:1265-1271.

Jiang, H., Fry, J., and Tisserat, N. 1998. Assessing irrigation management for its effects on disease and weed levels in perennial ryegrass. Crop Sci. 38:440-445.

Kackley, K. E., Grybauskas, A. P., Dernoeden, P. H., and Hill, R. L. 1990. Influence of temperature-soil water status on the development of summer patch in Poa spp. Phytopathology 80:650-655.

Kaminski, J. E. 2008. Curative control of anthracnose basal rot on an annual bluegrass putting green, 2007. Plant Dis. Manag. Rep. 2:T006.

Kostka, S. J., Cisar, J. L., Short, J. R., and Mane, S. 1997. Evaluation of soil surfactants for the management of soil water repellency in turfgrass. Intl. Turfgrass Res. Soc. Res. J. 8:485-494.

Latin, R. 2011. A Practical Guide to Turfgrass Fungicides. APS Press, St. Paul, $\mathrm{MN}$.

McDonald, S. J., Dernoeden, P. H., and Bigelow, C. A. 2006. Dollar spot and gray leaf spot severity as influenced by irrigation, chlorothalonil, paclobutrazol, and a wetting agent. Crop Sci. 46:2675-2684.

Melvin, B. P., and Vargas, J. M. 1994. Irrigation frequency and fertilizer type influence necrotic ring spot of Kentucky bluegrass. HortScience 29:1028-1030.
Pinto, C. G., Laespada, M. E. F., Martín, S. H., Ferreira, A. M. C., Pavón, J. L. P., and Cordero, B. M. 2010. Simplified QuEChERS approach for the extraction of chlorinated compounds from soil samples. Talanta 81:385-391.

Schumann, G. L., Clark, J. M., Doherty, J. J., and Clarke, B. B. 2000. Application of DMI fungicides to turfgrass with three delivery systems. Pages 150-163 in: Fate and Management of Turfgrass Chemicals. J. M. Clark and M. P. Kenna, eds. American Chemical Society, Washington, DC.

Walker, N. R. 2013. Evaluation of post fungicide application irrigation on control of spring dead spot of bermudagrass in Oklahoma, 2012-2013. Plant Dis. Manag. Rep. 8:T011.

Wong, F. P. and Corza, J. 2005. Control of summer patch and anthracnose on an annual bluegrass green in southern California, 2004. Fungicide Nematic. Tests 60:T058.

Wong, F. P., and Rios, J. C. 2008. Evaluation of Insignia fungicide and surfactants for curative control of southern blight in southern California, 2007. Plant Dis. Manag. Rep. 3:T004.

Wu, L., Liu, G., Yates, M. V., Green, R. L., Pacheco, P., Gan, J., and Yates, S. R. 2002 Environmental fate of metalaxyl and chlorothalonil applied to a bentgrass putting green under southern California climatic conditions. Pest Manag. Sci. 58:335-342. 